\title{
The effect of CTLA-4 A49G polymorphism on rheumatoid arthritis risk: a meta-analysis
}

\author{
Gang $\mathrm{Li}^{1}$, Fengjun Shi ${ }^{*}$, Jingchen $\mathrm{Liu}^{2}$ and $\mathrm{Ye} \mathrm{Li}^{2}$
}

\begin{abstract}
Background: Recently, a number of studies have been performed to explore the association between CTLA-4 A49G polymorphism and rheumatoid arthritis (RA). However, the results of previous works are still controversial and ambiguous.

Methods: In this work, we attempted to perform an updated meta-analysis of available case-control study in order to assess the association between CTLA-4 A49G polymorphism and RA risk. We searched the various citation databases without limits on languages. Article searching was performed by screening the references of retrieved studies manually. Odds ratios (OR) and $95 \%$ confidence intervals $(95 \% \mathrm{Cl})$ were calculated to evaluate the strength of the association.

Results: We totally compiled 27 studies in 24 articles (9805 RA patients and 10691 control subjects) into our meta-analysis work. We found significant association between CTL-A4 A49G polymorphism and RA risk (GG vs. AA: $\mathrm{OR}=1.13,95 \% \mathrm{Cl}=1.03-1.23 ; \mathrm{GA}$ vs. $\mathrm{AA}: \mathrm{OR}=1.19,95 \% \mathrm{Cl}=1.07-1.33 ; \mathrm{GA}+\mathrm{GG}$ vs. $\mathrm{AA}: \mathrm{OR}=1.18,95 \% \mathrm{Cl}=1.07-1.29)$. In the subgroup analysis by ethnicity, evidences of significantly increased risk was also found in both Asian (GG vs. AA: $\mathrm{OR}=1.34,95 \% \mathrm{Cl}=1.15-1.55 ; \mathrm{GA}+\mathrm{GG}$ vs. $\mathrm{AA}: \mathrm{OR}=1.24,95 \% \mathrm{Cl}=1.08-1.41$ ) and Caucasian population (GA vs. AA: $\mathrm{OR}=1.19,95 \% \mathrm{Cl}=1.03-1.37 ; \mathrm{GA}+\mathrm{GG}$ vs. $\mathrm{AA}: \mathrm{OR}=1.14,95 \% \mathrm{Cl}=1.01-1.29)$. No evidence of publication bias was found in this work.
\end{abstract}

Conclusions: Our meta-analysis suggests that CTLA-4 A49G polymorphism was associated with RA risk. Virtual Slides: The virtual slide(s) for this article can be found here: http://www.diagnosticpathology.diagnomx.eu/ vs/13000_2014_157

Keywords: Rheumatoid arthritis, CTLA-4, Polymorphism

\section{Background}

Rheumatoid arthritis (RA) is a common chronic inflammatory autoimmune disease characterized by significant disability and early mortality. RA affects $\sim 1 \%$ of the adults worldwide [1]. Although its etiology has not been determined, RA has been regarded as a complex autoimmune disorder characterized by a chronic T-cell response. So, genes involved in $\mathrm{T}$-cell response regulation might be important determinants of RA susceptibility.

The cytotoxic T-lymphocyte antigen 4 (CTLA-4) is an inhibitory receptor predominantly expressed on the activated and regulatory $\mathrm{T}$ lymphocytes [2]. It plays an important role in regulating T-cell activation. Several

\footnotetext{
*Correspondence: junfeng_shi001@163.com

'Department of Orthopaedics, Daqing General Hospital Group Oilfield General Hospital, Daqing 163001, China

Full list of author information is available at the end of the article
}

studies have documented that polymorphism of CTLA-4 A49G have remarkable effects on the susceptibility to autoimmunity [3]. A49G (rs231775) polymorphism, located in the first exon region of CTLA-4 gene, was identified as a functional single nucleotide polymorphism with a $\mathrm{A}$ to $\mathrm{G}$ change. This polymorphism has been shown to be associated with the susceptibility of diverse diseases [4-8], including RA. The results of previous reports on the possible association of CTLA-4 A49G polymorphism with RA risk remain controversial and ambiguous. To our knowledge, the issue of whether CTLA-4 A49G polymorphism can increase RA risk remains largely uncertain. A comprehensive meta-analysis can provide a reliable estimate in genetic association studies. In this work, we conducted a quantitative meta-analyses that increased statistical power to derive a more precise estimation of the relationship. 


\section{Methods}

\section{Study identification and selection}

A systematic literature search was carried out in the PubMed, IS Web and Chinese National Knowledge Infrastructure (CNKI) database with the terms of "CTLA-4", "rheumatoid arthritis", "polymorphism", "variation". Two investigators independently screened the information including the titles, abstracts and full texts to determine inclusion carefully. No language restrictions were used in our literature search.

\section{Data extraction}

The following inclusion criteria were used to select related literatures for the meta-analysis: (1) studies about the association between CTLA-4 A49G polymorphism and RA risk; (2) a case-controlled RA study of CTLA-4 A49G polymorphism with complete genotype distribution data; (3) studies on sufficient data and the original data from case-control studies. The following information were extracted from included studies: first author, year of publication, original country, ethnicity of the sample and genotype distributions.

\section{Statistical analysis}

The pooled odds ratios (ORs) with the corresponding 95\% confidence intervals (95\% CI) were used to evaluate the strength of association between the polymorphism of CTLA-4 A49G and RA risk. Four models were estimated: the co-dominant model (GG vs. AA, GA vs. AA), dominant model (GA + GG vs. AA) and recessive model (GG vs. GA + AA), respectively. Subgroup analyses were performed by ethnicity.

At first, we evaluated the HWE in the controls for each study using chi-square and a $\mathrm{P}<0.05$ was considered as significant disequilibrium. Statistical heterogeneity among the studies was gauged by the Chi-square

Table 1 Main characteristics of studies included in our work

\begin{tabular}{|c|c|c|c|c|c|c|c|}
\hline \multirow[t]{2}{*}{ First author } & \multirow[t]{2}{*}{ Year } & \multirow[t]{2}{*}{ Location } & \multirow[t]{2}{*}{ Ethnicity } & \multicolumn{3}{|c|}{ Case/controls } & \multirow[t]{2}{*}{ HWE } \\
\hline & & & & GG & GA & AA & \\
\hline Seidl & 1998 & Germany & Caucasian & $37 / 68$ & $138 / 210$ & $83 / 179$ & 0.88 \\
\hline Matsushita & 1999 & Japan & Asian & $200 / 56$ & 199/72 & $62 / 22$ & 0.98 \\
\hline Gonzalez-Escribano & 1999 & Spain & Caucasian & $10 / 30$ & $63 / 103$ & $65 / 172$ & 0.06 \\
\hline Barton & 2000 & Spain & Caucasian & $14 / 12$ & $57 / 70$ & $65 / 62$ & 0.44 \\
\hline Yanagawa & 2000 & Japan & Asian & $29 / 78$ & $50 / 88$ & $6 / 34$ & 0.56 \\
\hline Hadj & 2001 & Tunisia & African & $23 / 68$ & $27 / 62$ & $10 / 20$ & 0.33 \\
\hline Milicic & 2001 & UK & Caucasian & $63 / 73$ & $223 / 213$ & 135/166 & 0.94 \\
\hline Lee & 2002 & Korea & Asian & $41 / 49$ & $35 / 29$ & $10 / 8$ & 0.49 \\
\hline Vaidya & 2002 & UK & Caucasian & $20 / 45$ & $65 / 158$ & $38 / 146$ & 0.97 \\
\hline Lee & 2003 & China & Asian & $103 / 85$ & $67 / 100$ & $16 / 18$ & 0.32 \\
\hline Liu & 2004 & Taiwan & Asian & $14 / 21$ & $42 / 50$ & $9 / 10$ & 0.07 \\
\hline Barton & 2004 & UK & Caucasian & $34 / 29$ & $55 / 68$ & $43 / 59$ & 0.49 \\
\hline Lei & 2005 & China & Asian & $148 / 86$ & $138 / 125$ & $40 / 39$ & 0.84 \\
\hline Takeuchi & 2006 & Japan & Asian & $49 / 44$ & $39 / 49$ & $12 / 11$ & 0.88 \\
\hline Suppiah & 2006 & UK & Caucasian & $40 / 92$ & $144 / 241$ & $92 / 142$ & 0.85 \\
\hline Tsukahara & 2008 & Japan & Asian & $636 / 181$ & $668 / 194$ & $186 / 73$ & 0.23 \\
\hline Walker & 2009 & Canada & Caucasian & $177 / 179$ & $554 / 576$ & 409/493 & 0.87 \\
\hline Munoz-Valle & 2010 & Mexico & Mexican & $42 / 34$ & $102 / 82$ & $55 / 83$ & 0.22 \\
\hline Plant (F) & 2010 & France & Caucasian & $96 / 15$ & $315 / 75$ & $273 / 72$ & 0.77 \\
\hline Plant (Ge) & 2010 & Germany & Caucasian & $37 / 94$ & $111 / 83$ & $72 / 83$ & 0.44 \\
\hline Plant (Gr) & 2010 & Greece & Caucasian & $26 / 33$ & 133/107 & $113 / 147$ & 0.15 \\
\hline Plant (U) & 2010 & UK & Caucasian & $146 / 410$ & $451 / 1255$ & 407/994 & 0.91 \\
\hline Benhatchi & 2011 & Slovakia & Caucasian & $6 / 5$ & $33 / 25$ & $18 / 21$ & 0.82 \\
\hline Rocha & 2011 & Brail & Caucasian & $9 / 3$ & 29/15 & $32 / 12$ & 0.86 \\
\hline Tang & 2013 & China & Asian & $652 / 474$ & $642 / 535$ & 195/191 & 0.154 \\
\hline Alfadhli & 2013 & Kuwait & Asian & $10 / 14$ & $30 / 86$ & $74 / 182$ & 0.65 \\
\hline Liu & 2013 & China & Asian & 77/130 & $111 / 125$ & $25 / 48$ & 0.16 \\
\hline
\end{tabular}


Table 2 Results of meta-analysis for CTLA-4 A49G polymorphism and RA risk

\begin{tabular}{|c|c|c|c|c|c|c|c|c|}
\hline \multirow[t]{2}{*}{ Groups } & \multicolumn{2}{|c|}{ GG vs $A A$} & \multicolumn{2}{|c|}{ GA vs $A A$} & \multicolumn{2}{|c|}{$G A+G G$ vs $A A$} & \multicolumn{2}{|c|}{ GG vs $G A+A A$} \\
\hline & P-value & OR $(95 \% \mathrm{Cl})$ & P-value & OR $(95 \% \mathrm{Cl})$ & $P$-value & OR $(95 \% \mathrm{Cl})$ & $P$-value & OR $(95 \% \mathrm{Cl})$ \\
\hline Total & 0.009 & $1.13(1.03,1.23)$ & 0.001 & $1.19(1.07,1.33)$ & 0.001 & $1.18(1.07,1.29)$ & 0.66 & $1.03(0.91,1.17)$ \\
\hline Asians & 0.001 & $1.34(1.15,1.55)$ & 0.083 & $1.16(0.98,1.37)$ & 0.002 & $1.24(1.08,1.41)$ & 0.099 & $1.14(0.97,1.35)$ \\
\hline Caucasian & 0.991 & $1.00(0.89,1.12)$ & 0.015 & $1.19(1.03,1.37)$ & 0.042 & $1.14(1.01,1.29)$ & 0.51 & $0.93(0.77,1.14)$ \\
\hline
\end{tabular}

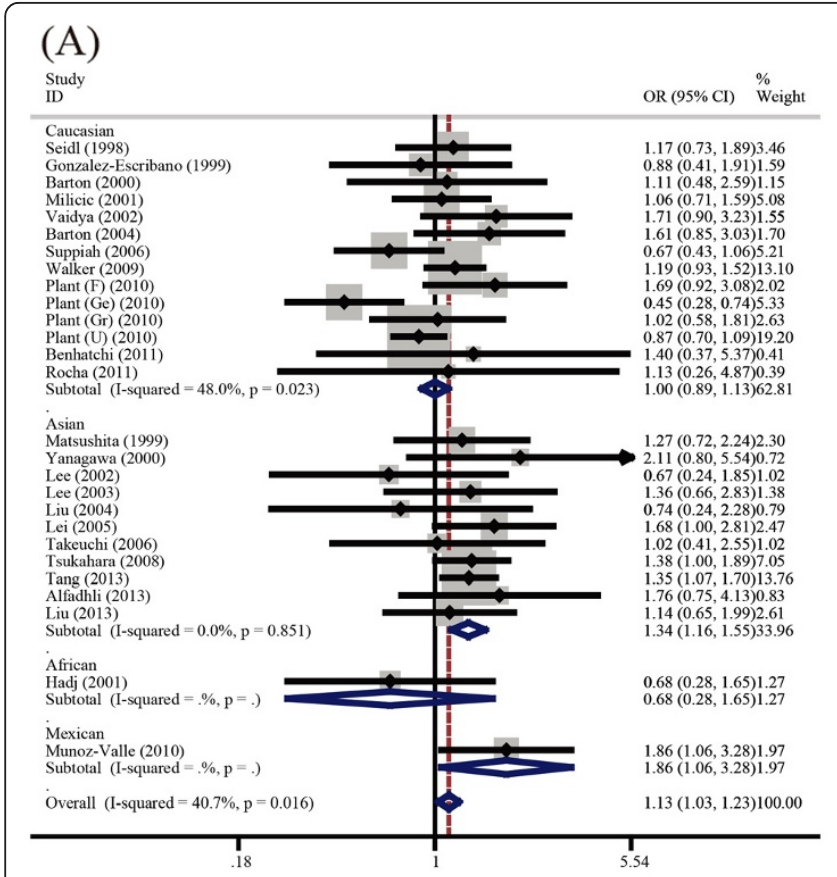

(B)

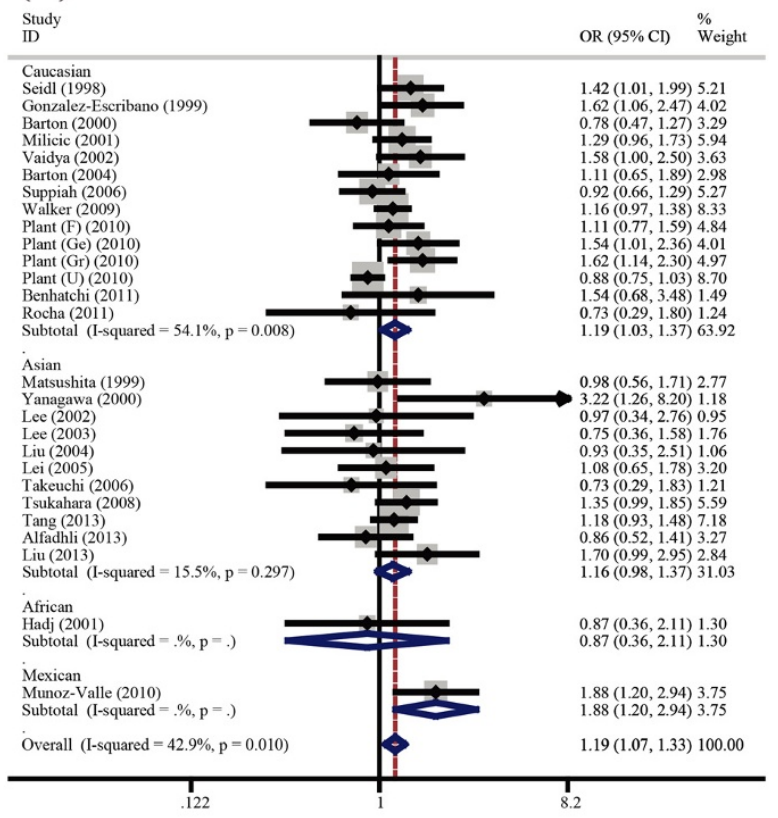

(C)

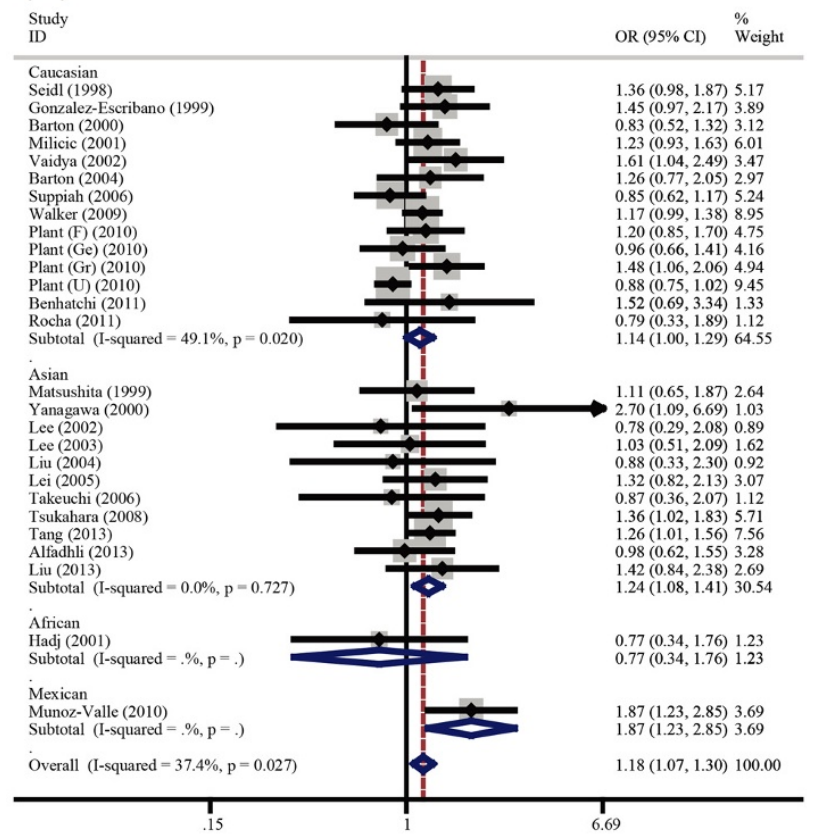

(D)

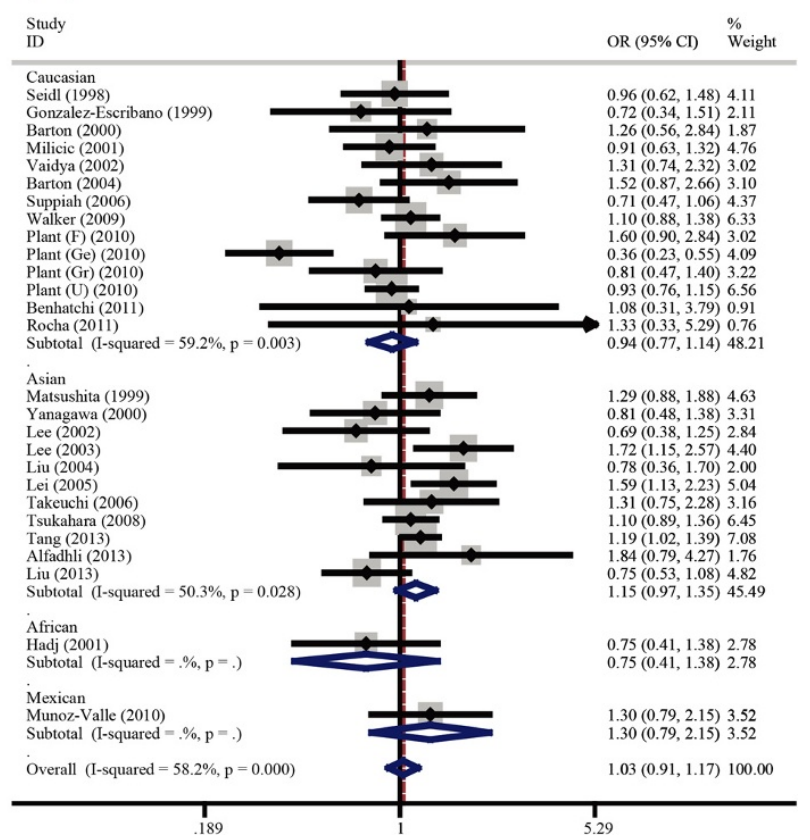

Figure 1 Forest plots for the overall association between CTLA-4 A49G polymorphism and RA risk A) GG vs. AA; B) GA vs. AA; C) $G A+G G$ vs. $A A$; D) $G G$ vs. $G A+G G$. 
Table 3 Results of Egger's test and Begg's test

\begin{tabular}{lllllll}
\hline Comparison & \multicolumn{3}{l}{ Egger's test } & & \multicolumn{2}{c}{ Begg's test } \\
\cline { 2 - 3 } & $\boldsymbol{t}$ & $\boldsymbol{P}$ & $\mathbf{9 5 \%} \mathrm{Cl}$ & & $\boldsymbol{Z}$ & $\boldsymbol{P}$ \\
\hline GG vs AA & 0.31 & 0.76 & $(-0.92,1.25)$ & & 0.67 & 0.51 \\
GA vs AA & 1.02 & 0.32 & $(-0.54,1.61)$ & 0.33 & 0.74 \\
GA + GG vs AA & 1.07 & 0.29 & $(-0.49,1.55)$ & 0.67 & 0.51 \\
GG vs GA + AA & -0.55 & 0.58 & $(-1.62,0.94)$ & 0.08 & 0.93 \\
\hline
\end{tabular}

based on Q-test. A P value greater than 0.1 for the Q-test indicates no significant heterogeneity existing among studies, and the pooled OR estimation was performed using the fixed-effects model (the Mantel-Haenszel method). Otherwise, the random-effects model (DerSimonian and Laird method) was used. Potential publication bias of literatures was analyzed through the Egger's linear regression test with a funnel plot. All statistical analyses were performed with STATA version 11.0 (Stata Corporation, College Station, TX). All the $P$ values were calculated using a two-sided test and $P<0.05$ were considered as statistically significant.

\section{Results}

\section{Study characteristics}

A total of $\mathrm{xx}$ articles were retrieve after the first search in various databases. After literature selection, 43 studies about the association of CTLA-4 A49G polymorphism with RA risk were identified and screened for data retrieval. Among which, 16 studies were irrelevant. At last, a total of 27 eligible independent case-control studies in 24 articles were included [9-33]. The characteristics of selected studies are summarized in Table 1. All of the studies indicated that the genotypic distribution of the controls was consistent with Hardy-Weinberg equilibrium.

\section{Quantitative synthesis}

All of the main results of the meta-analysis were shown in Table 2. Overall, significant associations between CTLA-4 A49G polymorphism and RA risk was found (GG vs. $\mathrm{AA}: \mathrm{OR}=1.13,95 \% \mathrm{CI}=1.03-1.23$; $\mathrm{GA} v s$. $\mathrm{AA}: \mathrm{OR}=1.19,95 \% \mathrm{CI}=1.07-1.33 ; \mathrm{GA}+\mathrm{GG} v s . \mathrm{AA}$ : $\mathrm{OR}=1.18,95 \% \mathrm{CI}=1.07-1.29$ ) (Figure 1 ). Next, we performed a further analysis on data stratified by ethnicity groups with the attempt to search for possible factors that might impact the results. In the subgroup analysis by ethnicity, evidences of significantly increased risk was also found in both Asian (GG vs. AA: OR $=1.34$, 95\% $\mathrm{CI}=1.15-1.55 ; \mathrm{GA}+\mathrm{GG}$ vs. $\mathrm{AA}: \mathrm{OR}=1.24,95 \%$ $\mathrm{CI}=1.08-1.41$ ) and Caucasian population (GA $v s$. AA: $\mathrm{OR}=1.19,95 \% \mathrm{CI}=1.03-1.37 ; \mathrm{GA}+\mathrm{GG}$ vs. AA: $\mathrm{OR}=1.14,95 \% \mathrm{CI}=1.01-1.29)$ in different genetic models.

\section{Heterogeneity analysis}

Significant heterogeneity existed in all four genetic models (GG vs. AA: $P=0.016, \mathrm{I}^{2}=40.7 \%$; GA $v s$. AA: $P=0.01, \mathrm{I}^{2}=42.9 \% ; \mathrm{GA}+\mathrm{GG}$ vs. AA: $P=0.027, \mathrm{I}^{2}=$ $37.4 \%$; $\quad$ G $\quad$ s. $\left.\quad \mathrm{GA}+\mathrm{AA}: \quad P=0.00, \quad \mathrm{I}^{2}=58.2 \%\right)$.
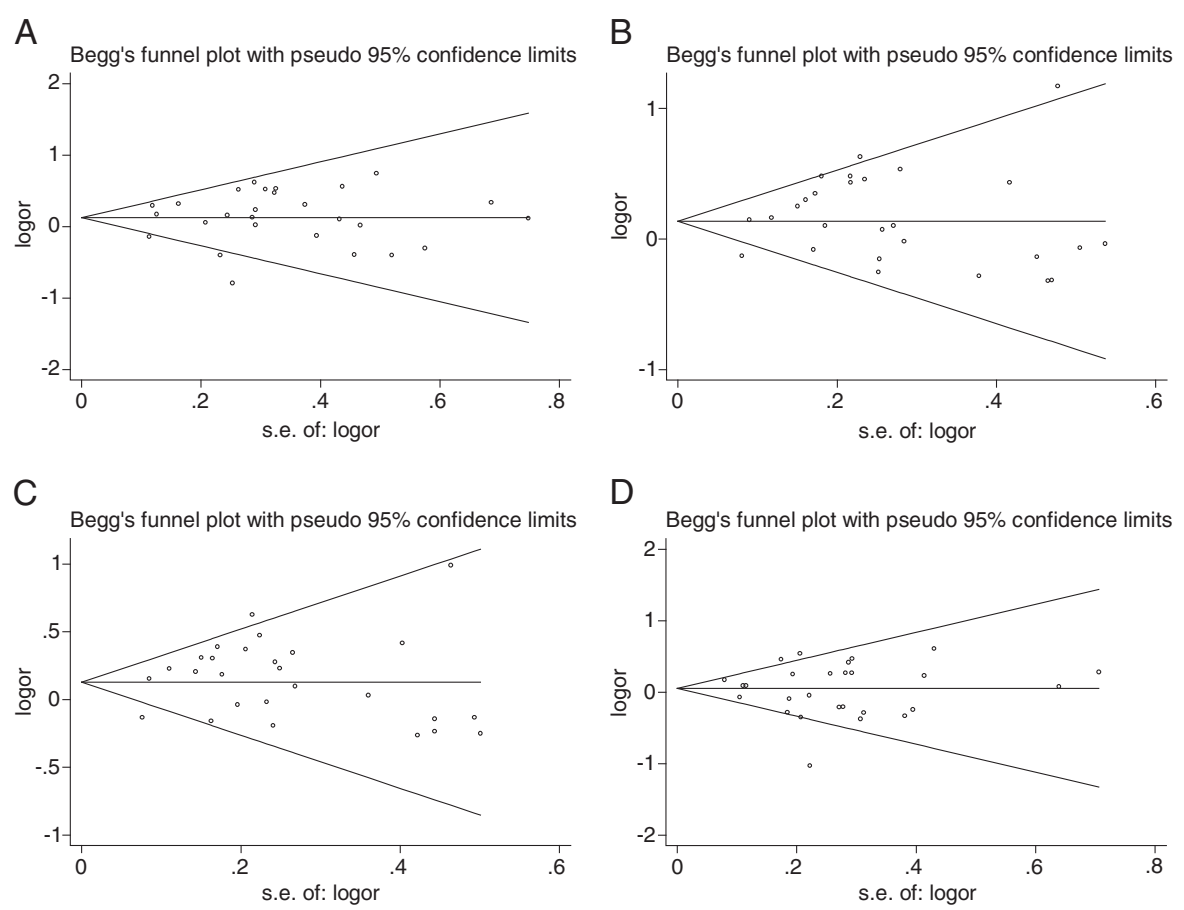

Figure 2 Funnel plots for A49G polymorphism of CTLA-4 in RA disease A) GG vs. AA; B) GA vs. AA; C) GA + GG vs. AA; D) GG vs. GA + GG. 
Therefore, the random-effect models were employed in all genetic models.

\section{Sensitivity analyses and publication bias}

Sensitivity analyses were performed to assess whether each individual study can affect the final results by using Begg's test and Egger's test. Neither the Begg's test nor the Egger's test provided any obvious evidences of publication bias (Table 3). The shapes of the funnel plots appeared to be symmetrical in all genetic models (Figure 2). These results showed that no individual study affected the final results in diverse genetic models using the exclusion method step by step.

\section{Discussion}

Although many efforts have been devoted for decades, the underlying molecular genetic basis of RA remains largely unknown. Recently, researches in the genetic susceptibility to RA have led to growing attentions to the study of association between gene polymorphisms and RA [34]. Large and well-designed genotype-phenotype investigations with robust statistical technical are required to detect these mild to moderate associations. Up to date, the association studies have been performed for CTLA-4 A49G polymorphism with respect to several disease susceptibility, such as liver disease, pancreatic cancer, primary biliary cirrhosis, etc. [5,35,36]. It has been realized that CTLA-4 A49G polymorphism play important role in disease disorders.

Several case-control studies have demonstrated inconsistent and even inverse relationship between CTLA-4 A49G polymorphism and RA risk. Until now, there are still no consensus results on the association of CTLA-4 A49G polymorphism and susceptibility of RA. In this work, we conducted a more comprehensive metaanalysis on the CTLA-4 A49G polymorphism and RA. For the overall data, it has been shown that CTLA-4 A49G polymorphism have an elevated association with RA risk. In the subgroup analysis by ethnicity, results suggested that strong evidences support the association between RA risk and CTLA-4 A49G polymorphism in both Asian and Caucasian populations. Previous metaanalyses works have reported that the CTLA-4 A49G polymorphism is associated with RA risk in Asians, but not in Caucasians using limited data [37,38]. In our work, we performed an up-dated meta-analyses, and found that A49G polymorphism is associated with RA risk in both Asians and Caucasians.

Many works have been devoted to examine the association between polymorphisms and RA risk [39,40]. As we know, genetic polymorphism of biomarkers is the key factor leading to the susceptibility of diseases. Our work suggests that CTLA-4 A49G polymorphism might be a potential clinical marker for RA. Important clinical insights are emerging, and this polymorphism provides new understanding of RA diagnostic advances. We provided useful reference for clinical medical treatment. However, there are still some limitations in our metaanalysis work. First, we were not able to take into account other factors because of lacking the original data, such as alcohol addictive, inflammation and other disease that may influence the association estimates; Second, although all eligible studies were summarized, the total sample size might have not been enough to make a convincing conclusion. So, when we performed stratified analysis of ethnicity, the number of each subgroup was relative smaller.

\section{Conclusions}

Our meta-analyses provided a more comprehensive evidence of the association between CTLA-4 A49G polymorphism and RA risk. The result showed that CTLA-4 A49G polymorphism is associated with susceptibility of RA.

\section{Competing interests}

None of the authors have any commercial or other association that might pose a conflict of interest. All authors are responsible for the content and writing of the paper.

\section{Authors' contributions}

FS participated in research design. GL, FS, JL and $Y L$ selected the articles, $G L$, FS, JL and YL performed data analysis. The manuscript was drafted by FS, and critically reviewed and discussed with the other co-authors. All the authors read and approved the final manuscript.

\section{Acknowledgements}

We thanks three anonymous reviewers for their insightful suggestions.

\section{Author details}

${ }^{1}$ Department of Orthopaedics, Daqing General Hospital Group Oilfield General Hospital, Daqing 163001, China. ²Department of Spine Surgery China-Japan Union Hospital, Jilin University, Changchun 130031, China.

Received: 18 June 2014 Accepted: 29 July 2014

Published: 16 August 2014

\section{References}

1. Costenbader KH, Chang SC, Laden F, Puett R, Karlson EW: Geographic variation in rheumatoid arthritis incidence among women in the united states. Arch Intern Med 2008, 168:1664-1670.

2. Ramirez-Soriano A, Lao O, Soldevila M, Calafell F, Bertranpetit J, Comas D: Haplotype tagging efficiency in worldwide populations in ctla4 gene. Genes Immun 2005, 6:646-657.

3. Teft WA, Kirchhof MG, Madrenas J: A molecular perspective of ctla-4 function. Annu Rev Immunol 2006, 24:65-97.

4. Antczak A, Pastuszak-Lewandoska D, Gorski P, Domanska D, Migdalska-Sek M, Czarnecka K, Nawrot E, Kordiak J, Brzezianska E: Ctla-4 expression and polymorphisms in lung tissue of patients with diagnosed non-small-cell lung cancer. Biomed Res Int 2013, 2013:576486.

5. Bajor DL, Vonderheide $\mathrm{RH}$ : Cracking the stone: Combination vaccination and ctla-4 blockade in pancreatic cancer. $J$ Immunother 2013, 36:362-364.

6. Demaria S, Kawashima N, Yang AM, Devitt ML, Babb JS, Allison JP, Formenti SC: Immune-mediated inhibition of metastases after treatment with local radiation and ctla-4 blockade in a mouse model of breast cancer. Clin Cancer Res 2005, 11:728-734.

7. Lee $\mathrm{YH}$, Song GG: A meta-analysis of the association between ctla- $4+49$ $\mathrm{a} / \mathrm{g},-318 \mathrm{c} / \mathrm{t}$, and il-1 polymorphisms and susceptibility to cervical cancer. Neoplasma 2014, 61:481-490. 
8. Wada S, Jackson CM, Yoshimura K, Yen HR, Getnet D, Harris TJ, Goldberg MV Bruno TC, Grosso JF, Durham N, Netto GJ, Pardoll DM, Drake CG: Sequencing ctla-4 blockade with cell-based immunotherapy for prostate cancer. J Trans Med 2013, 11:89.

9. Seidl C, Donner H, Fischer B, Usadel KH, Seifried E, Kaltwasser JP, Badenhoop K: Ctla4 codon 17 dimorphism in patients with rheumatoid arthritis. Tissue Antigens 1998, 51:62-66.

10. Matsushita M, Tsuchiya N, Shiota M, Komata T, Matsuta K, Zama K, Oka T, Juji T, Yamane A, Tokunaga K: Lack of a strong association of ctla-4 exon 1 polymorphism with the susceptibility to rheumatoid arthritis and systemic lupus erythematosus in japanese: An association study using a novel variation screening method. Tissue Antigens 1999, 54:578-584.

11. Gonzalez-Escribano MF, Rodriguez R, Valenzuela A, Garcia A, Garcia-Lozano JR, Nunez-Roldan A: Ctla4 polymorphisms in spanish patients with rheumatoid arthritis. Tissue Antigens 1999, 53:296-300.

12. Barton A, Myerscough A, John S, Gonzalez-Gay M, Ollier W, Worthington J: A single nucleotide polymorphism in exon 1 of cytotoxic t-lymphocyteassociated-4 (ctla-4) is not associated with rheumatoid arthritis. Rheumatology (Oxford) 2000, 39:63-66.

13. Yanagawa T, Gomi K, Nakao El, Inada S: Ctla-4 gene polymorphism in japanese patients with rheumatoid arthritis. J Rheumatol 2000 27:2740-2742.

14. Hadj Kacem H, Kaddour N, Adyel FZ, Bahloul Z, Ayadi H: Hla-dqb1 car1/ car2, tnfa ir2/ir4 and ctla-4 polymorphisms in tunisian patients with rheumatoid arthritis and sjogren's syndrome. Rheumatology (Oxford) 2001, 40:1370-1374

15. Milicic A, Brown MA, Wordsworth BP: Polymorphism in codon 17 of the ctla-4 gene $(+49 \mathrm{a} / \mathrm{g})$ is not associated with susceptibility to rheumatoid arthritis in british caucasians. Tissue Antigens 2001, 58:50-54.

16. Lee $\mathrm{YH}$, Choi SJ, Ji JD, Song GG: No association of polymorphisms of the ctla-4 exon $1(+49)$ and promoter $(-318)$ genes with rheumatoid arthritis in the Korean population. Scand J Rheumatol 2002, 31:266-270.

17. Vaidya B, Pearce SHS, Charlton S, Marshall N, Rowan AD, Griffiths ID, KendallTaylor P, Cawston TE, Young-Min S: An association between the ctla4 exon 1 polymorphism and early rheumatoid arthritis with autoimmune endocrinopathies. Rheumatology 2002, 41:180-183.

18. Lee CS, Lee YJ, Liu HF, Su CH, Chang SC, Wang BR, Chen TL, Liu TL: Association of ctla4 gene a-g polymorphism with rheumatoid arthritis in chinese. Clin Rheumatol 2003, 22:221-224.

19. Liu MF, Wang CR, Chen PC, Lin TL: Ctla-4 gene polymorphism in promoter and exon- 1 regions is not associated with chinese patients with rheumatoid arthritis. Clin Rheumatol 2004, 23:180-181.

20. Barton A, Jury F, Eyre S, Bowes J, Hinks A, Ward D, Worthington J: Haplotype analysis in simplex families and novel analytic approaches in a case-control cohort reveal no evidence of association of the ctla-4 gene with rheumatoid arthritis. Arthritis Rheum 2004, 50:748-752.

21. Lei C, Dongqing Z, Yeqing S, Oaks MK, Lishan C, Jianzhong J, Jie Q, Fang D, Ningli L, Xinghai H, Daming R: Association of the ctla-4 gene with rheumatoid arthritis in chinese han population. Eur J Hum Genet 2005, 13:823-828.

22. Takeuchi F, Kawasugi K, Mori M, Nakaue N, Kobayashi N, Kuwata S, Murayama T, Matsuta K: The genetic contribution of ctla-4 dimorphisms in promoter and exon 1 regions in japanese patients with rheumatoid arthritis. Scand J Rheumatol 2006, 35:154-155.

23. Suppiah V, O'Doherty C, Heggarty S, Patterson CC, Rooney M, Vandenbroeck K: The ctla4 + 49a/g and ct60 polymorphisms and chronic inflammatory arthropathies in northern ireland. Exp Mol Pathol 2006, 80:141-146.

24. Tsukahara S, Iwamoto T, Ikari K, Inoue E, Tomatsu T, Hara M, Yamanaka H, Kamatani N, Momohara S: Ctla-4 ct60 polymorphism is not an independent genetic risk marker of rheumatoid arthritis in a japanese population. Ann Rheum Dis 2008, 67:428-429.

25. Walker E, Hirschfield GM, Xu C, Lu Y, Liu X, Coltescu C, Wang K, Newman WG, Bykerk V, Keystone EC, Mosher D, Amos Cl, Heathcote EJ, Siminovitch KA: Ctla4/ icos gene variants and haplotypes are associated with rheumatoid arthritis and primary biliary cirrhosis in the canadian population. Arthritis Rheum 2009, 60:931-937.

26. Munoz-Valle JF, Valle Y, Padilla-Gutierrez JR, Parra-Rojas I, Rangel-Villalobos H, del Mercado MV, Ledezma-Lozano IY, Villafan-Bernal JR, Armendariz-Borunda J, Pereira-Suarez AL: The $+49 \mathrm{a}>\mathrm{g}$ ctla-4 polymorphism is associated with rheumatoid arthritis in mexican population. Clin Chim Acta 2010, 411:725-728.
27. Plant D, Flynn E, Mbarek H, Dieude P, Cornelis F, Arlestig L, Dahlqvist SR, Goulielmos G, Boumpas DT, Sidiropoulos P, Johansen JS, Ornbjerg LM, Hetland ML, Klareskog L, Filer A, Buckley CD, Raza K, Witte T, Schmidt RE, Worthington J: Investigation of potential non-hla rheumatoid arthritis susceptibility loci in a european cohort increases the evidence for nine markers. Ann Rheum Dis 2010, 69:1548-1553.

28. Benhatchi K, Jochmanova I, Habalova V, Wagnerova H, Lazurova I: Ctla4 exon $1 \mathrm{a} 49 \mathrm{~g}$ polymorphism in slovak patients with rheumatoid arthritis and hashimoto thyroiditis-results and the review of the literature. Clin Rheumatol 2011, 30:1319-1324.

29. Rocha MC, Santos LM, Bagatin E, Cohen Tervaert JW, Damoiseaux JG, Lido AV, Longhini AL, Torello CO, Queiroz ML: Genetic polymorphisms and surface expression of ctla-4 and pd-1 on t cells of silica-exposed workers. Int J Hyg Environ Health 2012, 215:562-569.

30. AlFadhli S: Overexpression and secretion of the soluble ctla-4 splice variant in various autoimmune diseases and in cases with overlapping autoimmunity. Genet Test Mol Biomarkers 2013, 17:336-341.

31. Shi Z, Cai L, Han X, Zhang D, Chen L, Jin J, Qian J, Du F, Ren D: Association between ctla-4 polymorphism and rheumatoid arthritis in Chinese. Zhonghua Fengshixue Zazhi 2007, 11:78-81.

32. Tang MJ, Zhou ZB: Association of the ctla- $4+49 a / g$ polymorphism with rheumatoid arthritis in chinese han population. Mol Biol Rep 2013, 40:2627-2631

33. Liu CP, Jiang JA, Wang T, Liu XM, Gao L, Zhu RR, Shen Y, Wu M, Xu T, Zhang XG: Ctla-4 and cd86 genetic variants and haplotypes in patients with rheumatoid arthritis in southeastern china. Genet Mol Res 2013, 12:1373-1382.

34. Zeng Z, Duan Z, Zhang T, Wang S, Li G, Gao J, Ye D, Xu S, Xu J, Zhang L, Pan F: Association between tumor necrosis factor-alpha (tnf-alpha) promoter $-308 \mathrm{~g} / \mathrm{a}$ and response to tnf-alpha blockers in rheumatoid arthritis: a meta-analysis. Mod Rheumatol 2013, 23:489-495.

35. Schott E, Witt H, Pascu M, van Boemmel F, Weich V, Bergk A, Halangk J, Muller T, Puhl G, Wiedenmann B, Berg T: Association of ctla4 single nucleotide polymorphisms with viral but not autoimmune liver disease. Eur J Gastroenterol Hepatol 2007, 19:947-951.

36. Joshita S, Umemura T, Yoshizawa K, Katsuyama Y, Tanaka E, Nakamura M, Ishibashi H, Ota M: Association analysis of cytotoxic t-lymphocyte antigen 4 gene polymorphisms with primary biliary cirrhosis in japanese patients. J Hepatol 2010, 53:537-541.

37. Lee YH, Bae SC, Choi SJ, Ji JD, Song GG: Association between the ctla-4 + $49 \mathrm{a} / \mathrm{g}$ polymorphism and susceptibility to rheumatoid arthritis: A meta-analysis. Mol Biol Rep 2012, 39:5599-5605.

38. Li X, Zhang C, Zhang J, Zhang Y, Wu Z, Yang L, Xiang Z, Qi Z, Zhang X, Xiao $X$ : Polymorphisms in the ctla-4 gene and rheumatoid arthritis susceptibility: a meta-analysis. J Clin Immunol 2012, 32:530-539.

39. Dai D, Chen Y, Ru P, Zhou X, Tao J, Ye H, Hong Q, Tang L, Pan G, Lin D, Gong Q, LV Y, Xu L, Duan S: Significant association between tap2 polymorphisms and rheumatoid arthritis: a meta-analysis. Diagn Pathol 2014, 9:129.

40. Kumar Y, Bhatia A, Minz RW: Antinuclear antibodies and their detection methods in diagnosis of connective tissue diseases: a journey revisited. Diagn Pathol 2009, 4:1.

\section{doi:10.1186/s13000-014-0157-0}

Cite this article as: Li et al.: The effect of CTLA-4 A49G polymorphism on rheumatoid arthritis risk: a meta-analysis. Diagnostic Pathology 2014 9:157. 